\title{
South Caucasus and Central Asia: The Belt and Road Initiative
}

\section{Kazakhstan Country Case Study}

Macroeconomics, Trade and Investment

South Caucasus and Central Asia

Equitable Growth, Finance and Institutions

World Bank 
This Country Case Study was prepared by the South Caucasus and Central Asia MTI in collaboration with the staff from other World Bank Global Practices covering the two sub-regions. The main objective of the Country Case Studies is to provide an informed view of the potential impact of the Belt and Road Initiative over the countries of Central Asia and Caucasus and policy recommendations to reap the benefits and mitigate risks. The main authors of the Country Case Study were Kazi Matin and Evgenij Najdov, with support from the Central Asia and Caucasus MTI team. The team is grateful for the guidance from Sandeep Mahajan (Practice Manager), peer reviewers Michele Ruta, Abdulaziz Faghi and Paul Vallely and for useful comments from Sascha Djumena and contributions from Violane Konar-Leacy, Victor Aragones and lan J.D. Gillson.

\section{Acronyms and Abbreviations}

$\begin{array}{ll}\text { BRI } & \text { Belt and Road Initiative } \\ \text { CAC } & \text { Central Asia and Caucasus } \\ \text { FDI } & \text { Foreign Direct Investment } \\ \text { GDP } & \text { Gross Domestic Product } \\ \text { ICT } & \text { Information and Communication } \\ & \text { Technology }\end{array}$

\section{Table of Contents}
MSR Maritime Silk Road
O\&M Operations and Maintenance
SOE State-Owned Enterprise
SREB Silk Road Economic Belt
WTO World Trade Organization

Executive Summary

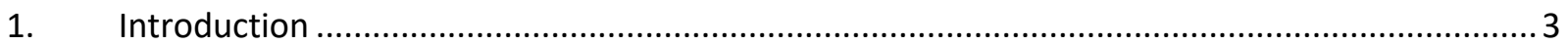

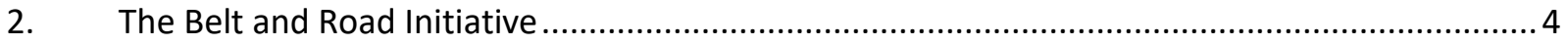

3. Improvements in Transport Infrastructure and Gaps ......................................................... 7

4. Estimates of BRI Impact on Shipment Time and Trading Cost.............................................. 9

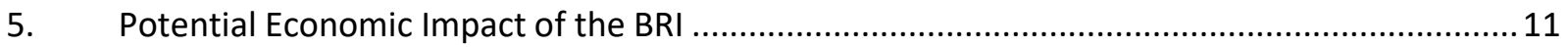

6. Complementary Policies to Accompany BRI Investment.......................................................17

7. Fiscal Risk of Scaling-Up Public Investment for BRI Infrastructure .........................................19 


\section{Executive Summary}

Kazakhstan is well placed to benefit from the Belt and Road Initiative (BRI) especially if the government implements further complementary reforms. The economy is the largest in Central Asia and its location is pivotal for the BRI. Notwithstanding a few gaps, its infrastructure is the most developed in the region. While the completion of BRI transport projects will lower Kazakh shipment time and increase FDI, non-oil exports and GDP, the bulk of that increase depends on trade facilitation and logistics reforms given the existing inefficiencies in border crossing. Complementary reforms to liberalize FDI, lower trade restrictions, and remove constraints to growth in agriculture will help maximize the benefits. Policies that improve connections with hinterlands, promote labor mobility and expand access to services across the country could reduce the spatial inequality that transport infrastructure investments typically generate.

BRI's support for cross-border transport infrastructure have benefited Kazakh connectivity. The government did not use much of China's financing but, as a land-locked country, it benefited from the easy availability of such financing for neighboring countries and the improvements in their transport network. Three of the BRI routes pass through Kazakh cities; two routes connect to Europe while the third transits through Uzbekistan and Turkmenistan to connect to Iran and West Asia, as well as to India using Iranian ports. The regular train services on BRI corridor routes to Europe are potentially game changers; they are frequent and reliable, with international and local logistics companies offering a growing range of more competitively priced services.

The estimated fall in shipment time and the rise in exports upon the completion of BRI transport projects will be magnified by trade facilitation and logistics reforms. BRI improvements in infrastructure reduce Kazakh shipment time by more than 8 percent and trade costs by 4 percent. But the size of that reduction could be two and half times greater if BRI transport projects are accompanied by reforms that halve border-crossing delays. Some of the benefits of reduction in shipment time are already visible. Kazakhstan's non-oil exports have grown in recent years, and the country has been attractive to foreign, including Chinese, investments in non-oil sectors.

Estimates also show that the BRI boost from a reduction in shipment time is much greater for non-oil exports. External demand for some of Kazakh exports (agriculture and processed foods, transport machinery and processed metals) is estimated to increase as their competitive production depends on time-sensitive imported inputs. Ensuring that exports respond to this will depend on those sectors attracting adequate foreign investors with the requisite technology to produce competitively and on the Kazakh government to implement complementary reforms that facilitate supply.

The BRI can potentially have a large effect on GDP. The impact of improved infrastructure alone on Kazakh GDP is estimated at around 6.5 percent; while improving trade facilitation and reducing tariffs along the corridors will add around 15 percent. However, taking into account the cost of building the infrastructure lowers the gains, the welfare gain for Kazakhstan to declines around 9 percent in a scenario of improved infrastructure, combined with reduced border delays and lowering of tariffs. This highlights the importance of the complementary reforms that improve the integration gains and that strengthen fiscal institutions and governance to ensure welfare gains are substantial.

The spatial distribution of BRI benefits within a country could be quite uneven though policies could reduce the degree of spatial inequality. Developed urban hubs closer to border crossings typically gain more from transport projects. In Kazakhstan, Almaty and the region around it are more attractive and stand to benefit. But if workers can move more easily across the country to where labor demand is higher and provision of public services improves across the country, gains could be distributed better. 
Kazakhstan is well placed to invest in BRI projects while ensuring its debt sustainability and continuing to strengthen its fiscal institutions. Total public debt had risen recently but only to around 20 percent of GDP in 2019, half of which is external. Total spending, including capital expenditure, is being reduced as part of fiscal consolidation. Public investment management framework is being strengthened.

Stronger regional cooperation is needed to reap the benefits of improved physical infrastructure. There has been no lack of cooperation initiatives in South Caucasus and Central Asia, though these appear to have had only limited usefulness, including due to selective coverage of trade and transport issues, complex rules, as well as lack of functioning dispute resolution mechanisms. In the case of Kazakhstan, closer cooperation with neighbors through harmonizing procedures could go a long way to improve the reliability of the transport corridors.

While the COVID-19 pandemic is reshaping supply chains, the integration agenda will remain a key ingredient of development strategies for countries like Kazakhstan. This note presents results of modeling exercises undertaken prior to the COVID-19 pandemic and does not capture the ongoing discussions about near-shoring production and reconfiguring global value chains. In fact, the role of global value chains in global trade had stalled even prior to the pandemic and COVID-19 has strained them further (World Bank, 2020). Still, a common transport infrastructure continues to make sense as the case for international trade, through differences in comparative advantage, specialization and economies of scale, remains strong. In fact, a number of the CAC countries, including Kazakhstan, could benefit from efforts of companies to diversify production from China. These countries will; however, need to pay more attention to debt sustainability and put more efforts in improving trade facilitation to better manage the risks from the slowdown of the global economy and ensure transport chains remain stable. 


\section{Introduction}

1. Kazakhstan is an upper-middle income, resource rich country. Its ascent to upper-middle income status was propelled by rising oil production and booming oil prices which pushed the average annual rate to above 7 percent during 2000-2013. The halving of world oil prices and lower export demand since resulted in a sharp slowdown with an average annual GDP growth rate of 2.2 percent in 2014-17. Growth picked up modestly recently but remains a far cry from the levels seen in early 2000s. Furthermore, the COVID-19 pandemic and the slump in commodity prices further dents the growth outlook.

2. Hydrocarbon production and exports will remain a driver of growth in future, but job creation will depend increasingly on non-oil tradeable sectors. Oil prices are unlikely to return to levels observed prior to the 2014 commodity price adjustment over the next two decades and oil production is projected to peak in 2030. ${ }^{1}$ If Kazakhstan is to become a 'high income' country by raising and sustaining annual growth rates of 6-7 percent, most of such growth and jobs will have to come from the non-oil tradable sectors. Several sectors offer potential for growth. The country could become a global leader in agricultural exports ${ }^{2}$, especially in wheat and meat given its endowments of cultivable land and pastures and rising demand from China and India (IFC 2017). In manufacturing, metals offer unexploited opportunities for exporting more high value, differentiated downstream 'worked' metal products, ferrous and non-ferrous (Mandel 2011). In services, transport and logistics can be an important source of future growth given the potential of Eurasian rail cargo traffic.

3. Notwithstanding the focus of Kazakh strategy documents on diversification, it has been difficult to achieve much progress, though recent reforms and events augur well for the future. High oil prices and excessive reliance on a vast and expanding state-owned enterprises (SOE) sector has discouraged private non-oil growth, but that may be changing. The government recently adopted a reform program that includes plans for privatization of large SOEs and began implementation of its ' 100 concrete steps', all aimed at shifting the balance of the economy towards the private sector. The country's accession to the WTO has also put it on the path to further liberalization. The opening of Uzbekistan and joint regional initiatives can unleash long-awaited expansion of regional trade and investment.

4. Kazakhstan is likely to be among the larger beneficiaries of the BRI. This is not surprising. As a large land locked country, its integration with the world is highly dependent on the quality of cross-border transport and that depends as much on its own transport network as it does on those of its neighbors. For more than a decade, Kazakhstan has invested substantially to improve its own network, but due to more limited improvements in trade facilitation and limitations of resources in many neighboring countries, the gaps have been difficult to fill. The focus of BRI on expanding transport infrastructure and economic integration and China's drive to connect its western and central regions more effectively to Europe and to West Asia provides an opportunity to address these gaps.

5. Reaping the full benefits of BRI and mitigating risks would depend on Kazakhstan's ability to push through complementary policies. The benefits of better transport infrastructure alone are relatively modest. Some of these benefits of faster transport are already evident in the recent improvements in rail transport because of the recent growth in regular train services along the two BRI corridors that pass through the country. More is in the offing when ongoing and planned BRI transport projects are completed. But, most of the benefits of better infrastructure will depend on Kazakh polices that reduce

\footnotetext{
${ }^{1}$ Kazakhstan ranks 11 th in the world in terms of proven oil reserves but based on its current rate of production, oil output is likely to peak in 2030. Also, world demand for hydrocarbons may be less robust over the next 25 years given the growing move towards electrics cars, truck and buses and the ongoing technical progress in renewable power generation and storage.

2 Kazakhstan's 2030 strategy envisages that the agricultural share of GDP would increase five-fold by 2050.
} 
border crossing delays as well as on polices that shift the economy's balance towards the private sector and non-oil exports.

6. This note assesses the potential impact of BRI over connectivity and the Kazakh economy. It looks at how, if fully implemented globally, the BRI is expected to achieve better transport connections and greater economic integration of participating BRI countries, discusses improvements in Kazakhstan's cross-border transport, electricity and ICT infrastructure to-date, and the potential impact of the completion of BRI transport projects on lowering Kazakh shipment time. It further looks at the likely economic impact of BRI reductions in shipment time on exports, FDI and GDP, the within country regional distribution of that impact and how complementary polices can enhance the positive impact and reduce regional inequity. Finally, it also examines the fiscal risk of scaling-up investment in BRI projects in the coming years without undermining medium-term debt sustainability.

Box 1: Quantifying the impact of BRI

The results presented in this Country Case study envisage the full implementation of all BRI transport infrastructure projects and as such are not an assessment of the impact or the cost and benefit of individual corridors or projects. The estimates were derived as part of the preparation of the World Bank's "Belt and Road Economics: Opportunities and Risks of Transport Corridors" report which uses empirical research and economic modeling to provide an objective analysis of opportunities and risks of BRI transports corridors. Estimates of the gains in shipment time were calculated by a combination of geographical data and network algorithms between 1,000 cities in 191 countries. The global network of railways and ports in 2013 is used to estimate the pre-BRI shipment times. The network is subsequently upgraded with planned infrastructure projects as part of the BRI to derive post-BRI shipment times. The projects were selected based on the criteria that the transport project is located on the corridor and that the project has been explicitly mentioned as part of BRI in an official document. This is neither exhaustive not an official list of BRI transport projects. On the two corridors that go through CAC, the report identifies around two dozen of transport connectivity projects. Out of these, around half were operational in 2019, six were under construction and the remaining were proposed.

Next, sectoral estimates of "value of time", considering each pair of countries and each sector, transform the reduction in shipment time into reductions of trade costs. Importantly, the analysis does not assume that all infrastructure projects are good. In fact, in a separate analysis of 68 BRI projects globally, Reed and Trubetskoy (2019) show that half of them generate little value when built in isolation; however, when the entire network of projects is built, this share falls to around one-third. This confirms the inter-dependence of projects as well as the importance of proper project selection and appraisal. Finally, a range of models (computable general equilibrium, structural general equilibrium and gravity models) are used to estimate the impact of the reduced trade costs on trade, FDI and GDP.

\section{The Belt and Road Initiative}

7. The BRI, announced in 2013, is an ambitious multi-year Chinese effort to improve international transport infrastructure and increase economic integration. Its goal of better transport connections and greater economic integration is to be achieved through substantial Chinese financing of transport and complementary infrastructure ${ }^{3}$ in the BRI countries, better policy coordination ${ }^{4}$ among those countries,

\footnotetext{
3 The total cost of BRI infrastructure program has been variously estimated at US\$1-4 trillion, with Chinese infrastructure commitment to date at US\$300-500 billion.

4 "Countries along the Belt \& Road may fully coordinate their economic development strategies and policies, work out plans and measures for regional cooperation, negotiate to solve cooperation-related issues and jointly provide policy support for practical cooperation and for large scale projects." (see pg 3 op. cit)
} 
and larger flows of outward foreign direct investment (FDI) from Chinese private firms and SOEs, all aimed at promoting "orderly and free flow of economic factors, highly efficient allocation of resources and deep integration of markets" (NDRC et al, 2015).

8. The initiative envisages implementation of a series of transport infrastructure projects along the Silk Road Economic Belt (SREB) land corridors and along the 21st Century Maritime Silk Road (MSR) sea-routes. The SREB seeks to improve China's transport overland to Europe and Asia through six BRI corridors: i) the New Eurasian Land Bridge Corridor; ii) the China - Central Asia - West Asia Corridor; iii) the China - Mongolia - Russia Corridor; iv) the China - Pakistan Economic Corridor (CPEC); v) the China Myanmar - Bangladesh - India (BCIM) Corridor and vi) the China - Indochina Peninsula Corridor. The MSR seeks to build or improve ports along the sea routes linking China's coast, one crossing the South China sea through the Malacca strait to the Indian Ocean and extending to Europe, and another crossing the South China sea and extending to the South Pacific. The BRI envisages investments not only in the corridor infrastructure (rail, road and port projects to improve cross-border transport), but also in complementary infrastructure like power and ICT. The BRI builds on a number of other transport initiatives aimed at improving connectivity ${ }^{5}$, though the time and money cost of cross-border transport remain high in the Central Asia and Caucuses (CAC) region.

Figure 1: BRI corridors

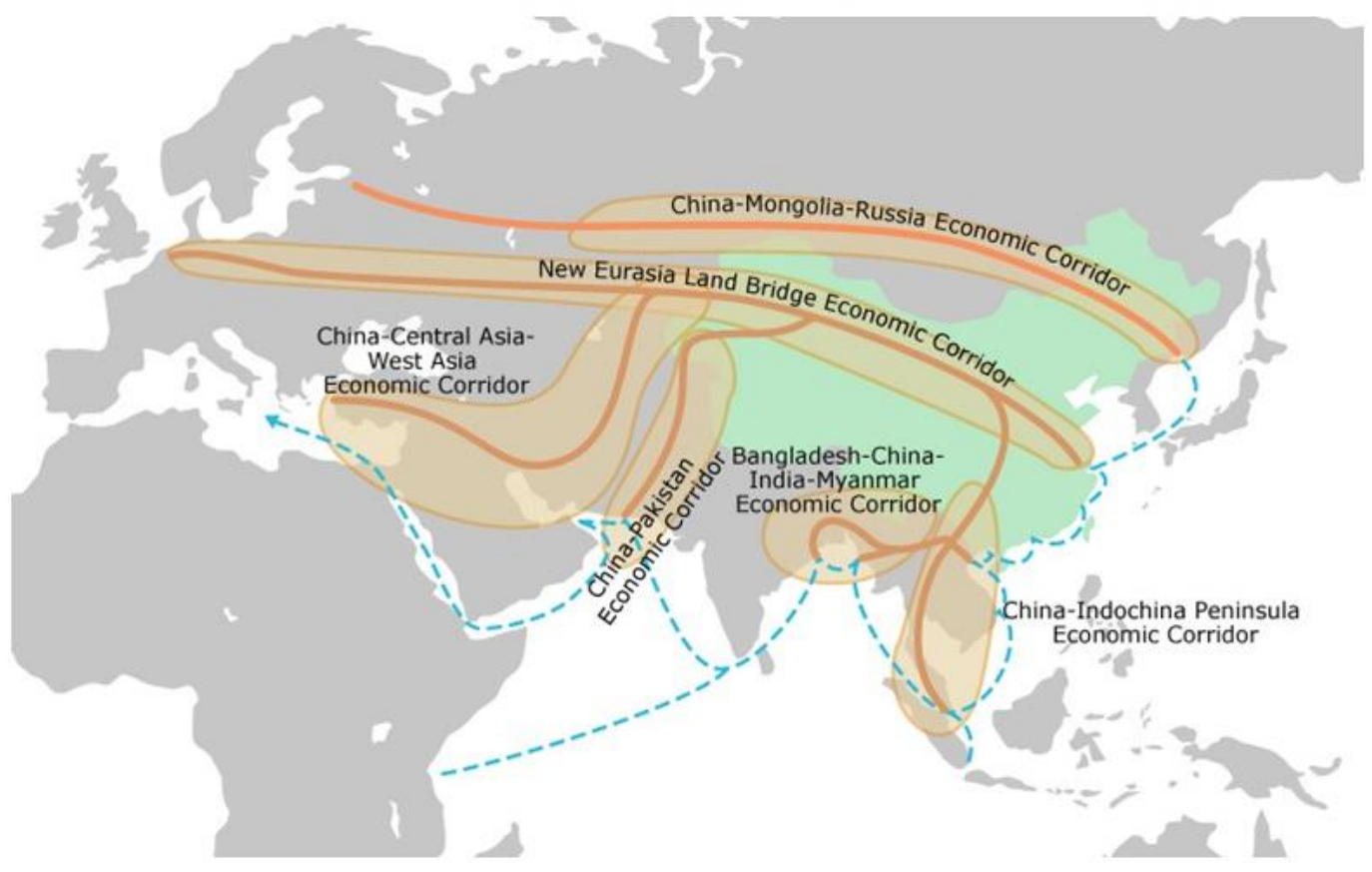

Source: Xinhua News Agency; Hong Kong Trade Development Council

9. The two BRI corridors passing through Central Asia and the Caucasus connect China to Europe and China to Iran and West Asia, respectively, through five routes, three of which go through Kazakh cities. The first uses two rail routes, one through Kazakhstan and Russia and the other through Kazakhstan, the Caucuses and Turkey. The second uses three routes, one through Kazakhstan, Uzbekistan and Turkmenistan, another one through Kyrgyz Republic, Uzbekistan and Turkmenistan and the third through Kyrgyz Republic, Tajikistan and Afghanistan.

\footnotetext{
5 These include the Transport Corridor Europe Caucasus Asia (TRACECA) initiative, the Central Asia Regional Economic Cooperation (CAREC) program and the Special Program for the Economies of Central Asia (SPECA) program.
} 
10. The five routes are potentially viable corridors. First, most of the completed, ongoing and planned BRI transport projects in the region are along these routes and thus provide CAC countries with their most direct exposure to BRI. Second, at least one major city of each country ${ }^{6}$ is on one or more of these routes and each country can thus connect faster to the large economies of China, Korea, Europe, Russia, Turkey, Iran, and West Asia, as well as to each other. Third, China's dependence on these routes for faster transport to the European cities and to cities in Iran and West Asia, means that both China and the CAC countries will have an interest to continually improve the operation of these corridors. Importantly, while the BRI focuses largely on the main transport corridors, improvements to the transport network at the lower levels (for example, secondary and feeder roads) are needed to ensure that the countries and populations benefit fully from the main corridors.

11. A good deal of the improvements in Kazakhstan's transport network, especially its eastward connections, started before BRI. Kazakhstan launched its own transport upgrading program more than a decade ago, financed by its ample oil revenues. China's 'Go West' strategy, the precursor to the BRI, focused on, among other things, transport (rail, road and pipeline) connections of its western region in two directions: towards the Chinese coast and towards the countries of Central Asia and beyond. Chinese investments in Kazakh oil fields and in pipelines began in $2006 .^{7}$ The BRI has accelerated the eastward reorientation of Kazakh transport, trade and FDI inflows.

\section{Box 2: BRI Corridors and routes passing through CAC}

The New Eurasian Land-bridge BRI Corridor connects China to Europe using two routes:

- Route 1: China (various cities, Urumqi, Alashankou) - Kazakhstan (Dostyk, Mointy, Nur-Sultan, Petropavl) Russia (Yekaterinburg, Moscow) - Belarus (Brest) - Poland (Małaszewicze) - Germany (Duisburg) and onwards to various European cities. (Note: all are operational rail connections).

- Route 2: China (various cities, Urumqi, Khorgas) - Kazakhstan (Altynkol, Almaty, Shu, Zharyk, Zhezqazghan, Saksaulskaya, Shalkar, Beyneu, Aktau) - Azerbaijan (Baku/Alyat, Ganja, Beyuk Kesik) - Georgia (Gardabani, Tbilisi, Akhalkalaki) - Turkey (Kars, Istanbul) and onwards by rail/road to various European cities. (Note: all are operational rail connections except Aktau to Baku, which is the Caspian Sea ferry segment).

China-Central Asia-West Asia BRI Corridor connects China to Iran/West Asia using three routes:

- Route 3: China (various cities, Urumqi, Khorgas) - Kazakhstan (Altynkol, Almaty) - Uzbekistan (Tashkent, Samarkand, Navoi) - Turkmenistan (Farab, Mary, Serakhs) - Iran (Sarakhs, Mashad) and onwards to West Asian cities (also India through Bandar Abbas) (Note: all are operational rail connections).

- Route 4: China (various cities, Kashgar) - Kyrgyz Republic (Irkeshtam, Osh) - Uzbekistan (Andijan, Pap, Tashkent, Samarkand, Navoi) - Turkmenistan (Mary, Serakhs) - Iran (Sarakhs, Mashad) and to West Asia (also India through Bandar Abbas). (Note: the route is mainly rail, except Kashgar -Irkeshtam - Osh segment by road)

- Route 5: China (various cities, Kashgar) - Kyrgyz Republic (Irkeshtam, Sary Tash) - Tajikistan (Karamyk, Dushanbe, Vahdat, Yavan, Nizhny Panj) - Afghanistan (Shir Khan Bandar, Kunduz, Mazar-e-sharif, Herat, Ghurian) - Iran (Torbat-e Heydarieh, Tehran) to West Asia (also, India thru Bandar Abbas). (Note: route connected partly by rail with two large segments, Kashgar - Irkeshtam - Sary Tash - Karamyk - Dushanbe and Nizhny Panj - Shir Khan Bandar - Kunduz - Herat - that are connected only by road today).

\footnotetext{
${ }^{6}$ Armenia is the only exception because of the closed Armenia-Azerbaijan border and so Armenian cities could connect to China overland by rail through Russia, which is probably not competitive.

${ }^{7}$ Chinese pipelines built in 2006 and 2009 and the Baku-Tiblisi-Ceyan pipeline, in 2005, expanded the market for Kazakh oil.
} 


\section{Improvements in Transport Infrastructure and Gaps}

12. Kazakhstan improved its own transport network by investing vigorously since the early 2000s, but a lot remains to be done. Domestically, its regions are separated by large distances making better transport essential. Internationally, it is landlocked and remote from seaports and thus good cross-border transportation depends not only on the quality of its own transport network but also on that of its neighbors. Before the BRI, the CAREC and SPECA programs of cross-border corridors helped increase and coordinate countries' investments in the region along their corridors. The high cost of transport investment in the region as well as the limitations of resources in many neighboring countries, left significant gaps in the quality and coverage of its cross-border transport infrastructure. Kazakhstan's quality of transport infrastructure is ranked better than most CAC countries by the World Bank's Logistics Performance Index (LPI), but it lags the average for the countries of the Europe and Central Asia region. In addition, outside urban areas, road access is on par with the other countries in Central Asia, a region that scores relatively low on rural accessibility, inhibiting the ability of the hinterlands to connect to markets.

Table 1: Infrastructure quality needs to improve ...

Transport infrastructure quality

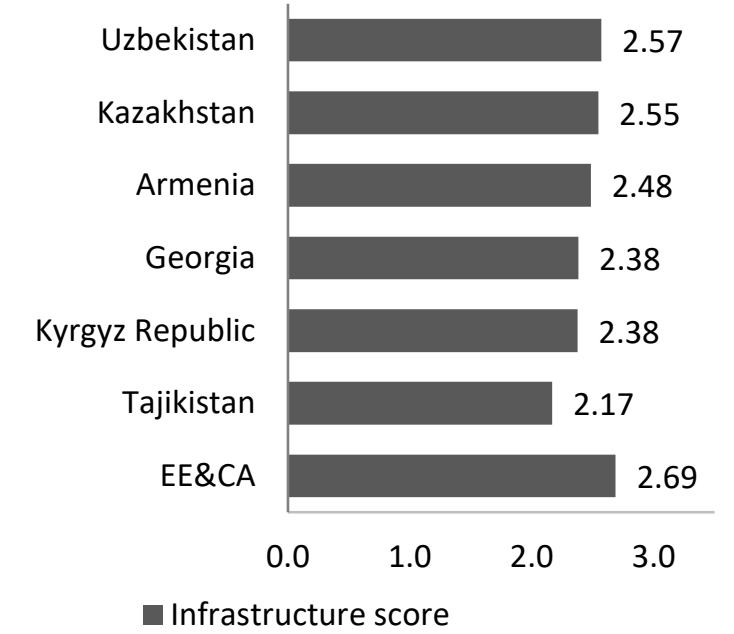

Source: World Bank Logistics Performance Index

\section{Rural Access Index}

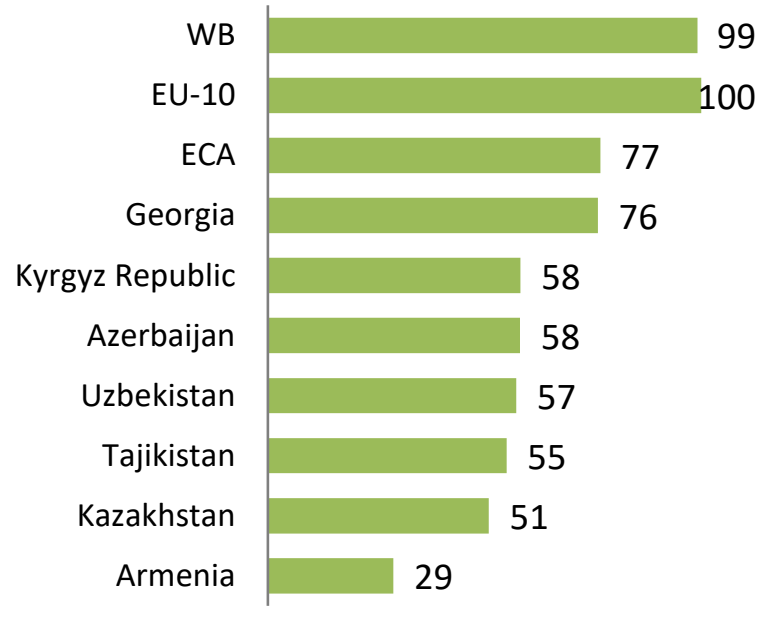

Note: rural people who live within $2 \mathrm{kms}$ of an all-season road as a proportion of the total rural population.

Source: Mikou at all (2019)

13. Inefficiencies and delays in trade facilitation in the region are typically also much greater than in many other regions and Kazakhstan performs poorly. In 2020, it was ranked $105^{\text {th }}$ in the world on 'Trading across Borders' by Doing Business and $71^{\text {st }}$ by the Logistics Performance Index (LPI). The Corridor Performance Measurement and Monitoring (CPMM) program conducted by freight forwarders under the supervision of the CAREC secretariat found that clearance took more than 40 hours at the border crossing between China and Kazakhstan (CPMM 2015). The above suggests a slow and difficult border-crossing at the various Kazakh border crossing points. Banya and others (2018) find that the shipment time required for Kazakhstan to trade with BRI partners is 15.4 days and with China, 12 days, which is good for the subregion but relatively high when compared to other countries and considering that Kazakhstan shares a border with China. 
14. Gradual liberalization in trade policy has been off-set by increasing prevalence of non-tariff measures. The simple average MFN tariff rate in Kazakhstan, a WTO member since 2015, has declined from close to 10 percent earlier this decade to 6.4 percent in 2018. This puts Kazakhstan on par with other Eurasian Economic Union (EEU) members from the sub-region (Armenia and the Kyrgyz Republic), below Azerbaijan (9 percent - 2015 data), Uzbekistan (14.9 percent - 2015 data) and Tajikistan (7.7 percent), but well above Georgia (1.5 percent). On the other hand, transposition of EEU standards and technical regulations resulted in greater prevalence of non-tariff measures which may add to trade costs.

15. Kazakhstan invested substantially in the expansion and upgrade of cross-border rail routes. While most of the upgrades in rail tracks along the first BRI corridor route were done before 2013, the investments along the second and third routes have been more recent. Upgrades (e.g. electrifying, double-tracking) of rail tracks, the modernization/expansion of Aktau port, the newly-built Khorgas dryport and terminal ${ }^{8}$ and several new rail segments were all done since then. Kazakhstan has also built and/or upgraded north-south cross-border rail routes. One of them connects Uzen northward to Russia and southward to Iran ${ }^{9}$ through cities in northwest Kazakhstan and Turkmenistan, travelling down the eastern side of the Caspian. The other connects Aktobe northward to western Russia and southward to Afghanistan through cities in southern Kazakhstan and in Uzbekistan.

Table 2: ... as should trade facilitation

Logistics Performance Index

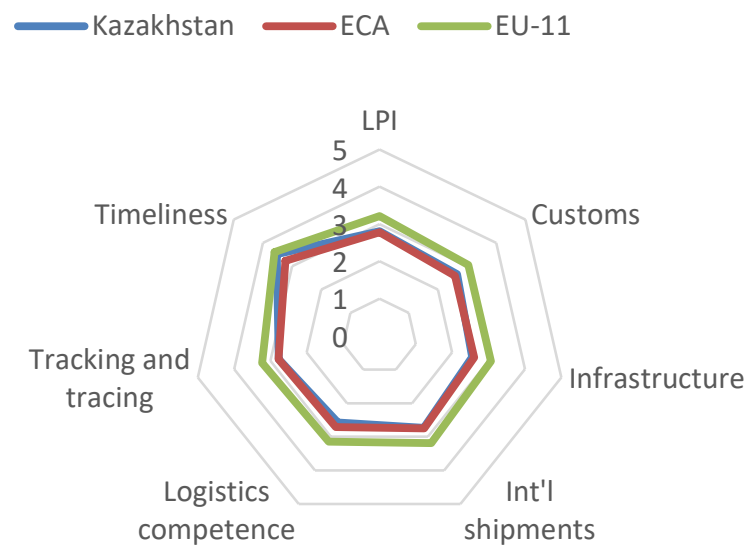

Source: Logistics Performance Index
Time to import and export

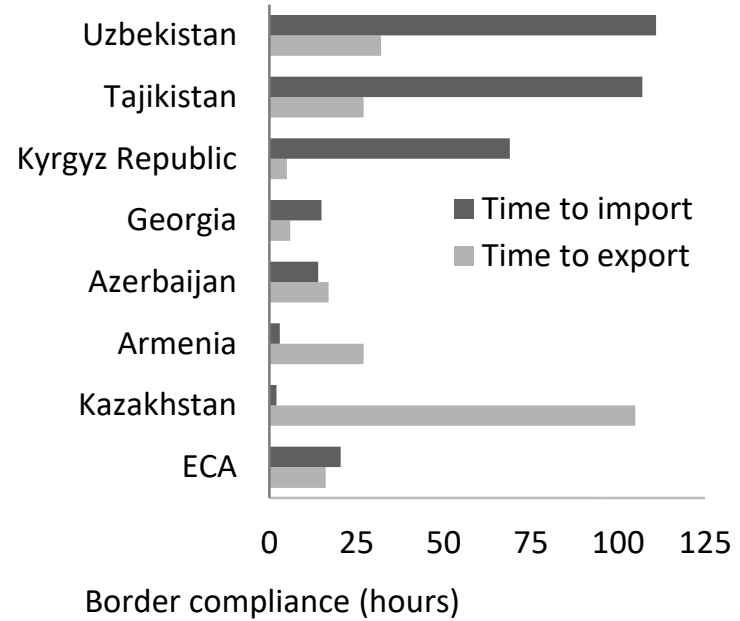

Source: Doing Business

16. Domestic connectivity has improved too. The two major cities of Almaty and Nur Sultan now have access to upgraded rail and road links with each other as well as with cities across its border. Almaty, Nur Sultan and Shymkent are connected to Tashkent by rail and road, to Bishkek by a modern road and to Dushanbe through a less developed but adequate multimodal rail and road route. Inside the country, Almaty and Nur Sultan are connected by rail and road to Kostanai in the wheat-growing agricultural north, to Aktobe, Atyrau and Aktau in the oil-rich west/northwest region and to Pavlodar and Karaganda in the manufacturing centers of the east.

17. The variety of cross-border rail services along the three BRI corridor routes has been considerably enhanced. A little over a decade ago rail transport between China and Europe was not much

\footnotetext{
${ }^{8}$ Agreement to build Khorgas was made in 2010, construction began in 2012 and partial operations started in 2013, with the rail connection extending to Lianyungang port with a container terminal for Kazakhstan.

${ }^{9}$ It also connects Kazakhstan to India through the Iranian ports of Bandar Abbas or Chahbahar.
} 
faster than shipment by sea. But since the first block train in 2011 travelled between Chongqing, China, and Duisburg, Germany, through Kazakhstan and Russia in 16 days (Arvis \& Rastogi 2015, Shephard 2016a), travel time and costs per container have continued to come down along the first and second routes. The variety and frequency of train services is much greater on the first route. But increasingly, international and local logistics companies are offering varied services including refrigerated containers, less-than-full-container-load consignments, door-to-door deliveries and pre-announced schedules on both routes. ${ }^{10}$ The frequency of trains from China to Europe through Kazakhstan has risen to more than 10 a day today, connecting many European and Chinese cities. The third BRI corridor route between China and Iran/West Asia through Kazakhstan and Uzbekistan started regular service from China relatively more recently.

18. The three BRI corridor routes passing through Kazakh cities have contributed to reducing travel times to destinations along those routes. Trains travel faster than before and several Kazakh cities, including Nur Sultan and Almaty, can now connect more speedily to cities in China, Turkey, Russia and of course Europe, as well as to those in Azerbaijan and Georgia along the first two BRI corridor routes.

19. Despite the investment so far, several infrastructure gaps in respect of upgrading rail tracks, rolling stocks, dry ports and logistics hubs remain. For example, some segments of BRI Corridor route one between Dostyk and Petropavlovsk, through Mointy and Astana, ares still single-tracked and unelectrified and need to be upgraded given the growing traffic on the route. The dry ports and rail/road terminals along the three BRI corridor rail routes need to be expanded and modernized. Except for the Nur Sultan, Almaty and Khorgas hubs or transport and logistics centers, others need upgrades in infrastructure. Some of these upgrades are already part of the Nurly Zhol infrastructure development program. ${ }^{11}$

\section{Estimates of BRI Impact on Shipment Time and Trading Cost}

20. The completion of BRI transport projects around the world, ${ }^{12}$ together with those in Kazakhstan and the CAC region, will reduce Kazakh shipment time. The BRI improvements in transport infrastructure increase the number of rail and port connections ${ }^{13}$ in the global transport network, improve the speed of travel along upgraded or newly-built rail segments and in seaports and add to the available options of routes for shippers to reach their destinations. Because all countries are linked in the global transport network, any fall in shipment time in one region affects those in other regions of the network, too. In other words, the average shipment time between Kazakhstan and its trading partners falls not only because of the transport projects in Kazakhstan and the CAC region, but also because of those in other countries and in other regions of the global transport network. ${ }^{14}$

\footnotetext{
10 The China-Europe trains started as a 'customer-driven' model of full 'block' trains organized by companies but has evolved increasingly to a 'retail model' of regular trains based on agreements between international logistics companies and operators/agencies in transit countries, where logistics companies organize train schedules.

11 A US\$9 billion five-year (2015-2019) government program announced in 2014 aimed at improving major infrastructure in the country. As of late-2018, the government reported that around 50 percent of the government allocation for roads (US\$2.2 billion) had been utilized.

12 BRI transport projects globally have been compiled and presented in in De Soyres 2018 and Reed and Trubetskoy 2019.

13 Most international trade is carried by sea with rail as the second most important mode of transport. Estimates of shipping times are based on the impact of the completion of BRI rail and port projects only.

14 The BRI is estimated to reduce the average shipping time for all country-pairs in the world from 22.9 days to 22.3 days (upper bound) i.e. a reduction of around 15 hours, including reductions for countries that do not host any BRI transport projects.
} 
21. The completion of BRI transport projects is estimated to lower Kazakhstan's average shipment time by between 4.4 and 8.3 percent (Baniya et al, 2019) ${ }^{15}$ Currently, it takes 15.4 days on average to trade between Kazakhstan and BRI partners (12 days in the case of trade with China). Under the upper bound scenario (Table 3), shipment time for trade with BRI partners will be shorter by more than one day. This is one of the larger reductions in shipment times (percentage wise) among BRI countries, partly because the country is home to many projects and has a pivotal location in the CAC region's cross-border network. Only Cambodia, Thailand, Kyrgyz Republic and Uzbekistan are estimated to have a larger decline in average shipment time. More importantly, the percentage reduction in Kazakh shipment time could be more than two and half times the upper-bound estimate shown above, if the completion of BRI transportprojects is accompanied by reforms in trade facilitation and logistics that halve the border-crossing delays (Baniya et al 2019, Figure 5).

Table 3: Investments will lower the time to trade Figure 2: as well as the costs of trade

\begin{tabular}{|l|r|r|r|r|}
\hline & \multicolumn{2}{|c|}{$\begin{array}{c}\text { Average time to } \\
\text { trade to }\end{array}$} & \multicolumn{2}{|c|}{$\begin{array}{c}\text { Reduction in } \\
\text { time to trade }\end{array}$} \\
\hline & BRI & China & $\begin{array}{r}\text { Lower } \\
\text { bound }\end{array}$ & $\begin{array}{r}\text { Upper } \\
\text { bound }\end{array}$ \\
\hline ARM & 15.5 & 32.1 & 2.2 & 2.8 \\
\hline AZE & 13.8 & 22.5 & 6.1 & 7.1 \\
\hline GEO & 14.6 & 32.6 & 2.6 & 3.5 \\
\hline KAZ & 15.4 & 12.0 & 4.4 & 8.3 \\
\hline KGZ & 20.7 & 15.2 & 8.5 & 12.9 \\
\hline TJK & 18.7 & 31.7 & 3.0 & 3.9 \\
\hline UZB & 17.3 & 27.0 & 13.6 & 15.2 \\
\hline
\end{tabular}

Lower bound refers to a scenario of preference for maritime links. In the upper bound, this preference is removed.

Source: Baniya et al 2019

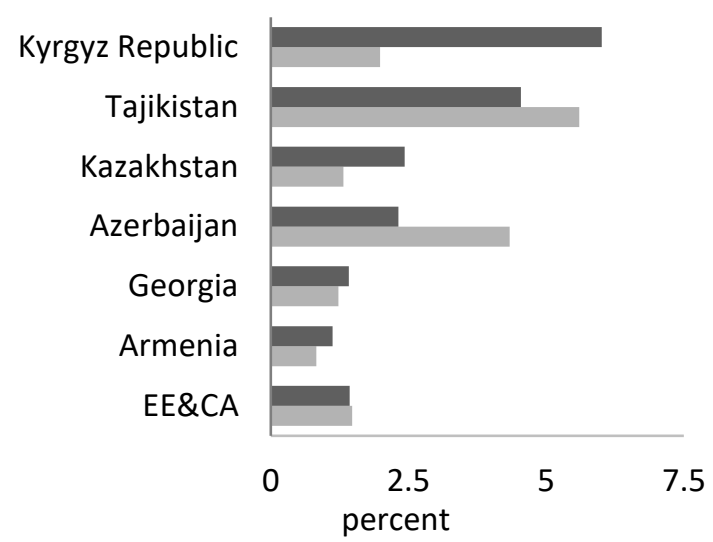

Export weighted Import weighted

22. Shipment time affects trade flows just as tariffs and freight costs do. Thus, reductions in shipment time, through either improvement in transport infrastructure and/or in the efficiency of border crossing, lower trade costs, too. But the same fall in shipment time in two countries can generate differing magnitudes of decline in trade cost because some goods are more time-sensitive than others and the composition of trade in respect of such goods may differ substantially between the two countries. A reduction in Kazakh shipment time by 8.3 percent (upper bound scenario above) because of BRI transport projects is estimated to lower Kazakhstan's export-weighted trade cost by 2.5 percent. ${ }^{16}$

\section{Box 3: Electricity and ICT infrastructure and gaps*}

The analysis in this note is focused on transport connectivity and economics; however, other infrastructure will also be important for countries to be able to reap the benefits of improved transport connectivity and this box provides some information on the infrastructure and gaps in energy and ICT.

Energy. Kazakhstan's power infrastructure, in terms of generation, transmission and distribution, is in better shape than others in Central Asia, but it faces a challenge of mobilizing substantial investment over the next decade to meet demand. After a mini-investment boom in the power sector in 2009-13 and falling demand after 2014 the pressure on generation has eased, outages at major power stations fell and reserve margins, though still low, rose. Key parts of the national transmission grid, especially the North-South interconnector, is frequently

\footnotetext{
15 The lower bound refers to a scenario where there is preference for maritime links where available. In the upper bound scenario, this preference is removed.

${ }^{16}$ Estimates from an unpublished note by Constantinescu et al (2019).
} 
congested making generators' non-discriminatory access uncertain. The distribution system is a weak link in the chain due to excessive fragmentation and insufficient modernization.

Though overall electricity supply and access in Kazakhstan is better than in other countries of Central Asia, business firms still view electricity issues as a major constraint. While the average number of days to obtain an electrical connection has come down substantially, the duration of power outages has halved and losses resulting from power outages decreased, the share of firms that report informal payments to obtain an electrical connection has increased and exceeded the BEEPs average.

Under Kazakhstan's Energy Concept 2030, 7,500 MW of new generation capacity will have to be added, which is estimated to cost more than US\$300 million a year. Though private investment is to be mobilized as part of the power strategy, it is likely to depend on regulatory reform in respect of tariffs, non-discriminatory access and investment rules. The country derives most of its power generation from coal thermal plants with targets for solar and wind power at 3 percent by 2020 and 10 percent by 2030.

ICT. Kazakhstan's ICT infrastructure has been growing rapidly. Kazakhstan has twelve international providers with an estimated total international bandwidth at the end of 2018 of 1,624,354 Mbps. This was a 26 percent increase over the prior year. It has eight international terrestrial fiber connections. Four providers have reported owning their own domestic long-haul and inter-city networks fiber networks.

Kazakhstan's vast territory, mountainous terrain and sparse population present challenges to internet infrastructure development. The country has more than 6,600 rural settlements, some of which are located in remote and hard-to-reach areas. Its immediate strategic priority is to provide broadband and affordable internet access to more than 1,200 rural settlements, using a PPP model to construct fiber-optic and satellite communications networks. The program also plans to develop next generation mobile infrastructure in all regional centers.

The regulatory framework needs to improve. There are regulatory limitations on fixed line ownership by foreign entities, which limits the number of operators that can own their own international gateways (only two, at present, which are both state-owned). The state continues to hold a significant share of the telecommunications sector, and telecom companies are legally required to interconnect with the state-owned incumbent network. While an open access policy is in place, its application is irregular. Weak tariff regulation results in expensive transit prices and hurts downstream providers.

*/ Energy information based on Aldayarov et al (2017); ICT on Raja (2019, unpublished).

\section{Potential Economic Impact of the BRI}

23. BRI transport projects globally will positively impact Kazakhstan's trade, FDI and GDP, but that impact is likely to be distributed unevenly across its regions. The BRI-induced fall in shipment time will raise exports and also change the composition towards more time-sensitive non-oil items. Higher FDI inflows into increasingly profitable opportunities in those exports and greater access to imported inputs will boost GDP. However, because different Kazakh regions and districts experience different degrees of reduction in shipment times, the export and GDP impact may be distributed unevenly. This note presents the results of the analysis undertaken prior to the COVID-19 pandemic and does not take capture the ongoing discussions about near-shoring production and reconfiguring global value chains. While the COVID-19 impact is likely to be profound, the case for international trade, through differences in comparative advantage, specialization and economies of scale, remains strong.

24. The government of Kazakhstan can magnify the impact of BRI on trade, FDI and GDP and reduce their inequitable regional distribution by complementary reforms in several areas. Reforms that improve trade facilitation, promote better logistics and transport services, and liberalize the country's trade further are likely to magnify the impact. Similarly, the liberalization of investment restrictions in both goods and services sectors can do the same for FDI. Also, complementary policies that enhances the 
mobility of labor across Kazakhstan's regions, improve road connections between hinterland and its major transport hubs and expand access to education and health services around the country could spread the benefits of faster transportation and greater economic integration more equitably within the country.

\section{Recent Trade Flows}

25. Kazakh trade boomed after $\mathbf{2 0 0 0}$ as oil, gas and metals exports increased and their rents trickled into higher domestic demand. Total trade grew more than five-fold between 2000 and 2018 to US\$93 billion as exports grew to above US\$60 billion ${ }^{17}$ in 2018 and imports reached above US\$32 billion. Oil and gas exports grew at a compound annual rate of around 13 percent a year facilitated largely by construction of new pipeline infrastructure and strong external demand. Metals and minerals exports grew by 9 percent, manufactures by 8 percent and agriculture exports by 13 percent.

26. Though Kazakh non-oil exports grew fast during this period, their share in total exports remained low. Hydrocarbons still dominate total exports with a share of 70 percent of total exports. The share of metals and minerals dipped to around 19 percent of exports, but seven-tenths of metal exports comprised of ores, concentrates and low-value unwrought products. ${ }^{18}$ Agricultural exports were around 5 percent of total exports in 2018, with half in wheat, three-tenths in vegetable products and only a negligible share in meat products. The share of manufactures was only 6 percent of exports with nearly two thirds in chemicals and another sixth in machinery (electrical) and transport.

27. The period until $\mathbf{2 0 1 3}$ witnessed a notable redirection of total trade towards China, though this trend has reversed slightly recently. China's share of Kazakh trade rose by more than 12 percentage points compared to 2000 to reach around 17 percent in 2013; however, China's share has recently stabilized around 13 percent reflecting lower exports to China. In contrast, the share of the European Union (EU) increased as most of the oil production was exported to EU markets. The share of the Russian Federation dipped by 10 percentage points. Today, China, is the third largest trading partner of Kazakhstan, having a higher share in Kazakh imports (16.7 percent) than in exports (10.3 percent).

Table 4: Share of Major Trading Partners in Kazakh Trade

(in \% of total)

\begin{tabular}{|l|c|c|c|c|c|c|}
\hline & \multicolumn{2}{|c|}{ EU } & \multicolumn{2}{c|}{ Russia } & \multicolumn{2}{c|}{ China } \\
\hline & 2000 & 2018 & 2000 & 2018 & 2000 & 2018 \\
\hline Total Trade & 23.3 & 40.6 & 28.1 & 18.2 & 5.5 & 12.5 \\
\hline Total Imports & 23.8 & 20.7 & 48.3 & 37.1 & 3.0 & 16.7 \\
\hline Total Exports & 23.0 & 51.2 & 17.7 & 8.2 & 6.8 & 10.3 \\
\hline
\end{tabular}

Source: IMF, Direction of Trade

28. In terms of composition, metals, minerals and fuels dominate Kazakh exports to China. Metals and minerals accounted for more than half of all exports to China in 2018. Oil and gas comprise around 30 percent while manufactures account for 12 percent, most of it in chemicals. Wheat and other agriculture account for only two percent each.

29. Also, little of Kazakhstan's manufactured exports participate in GVCs. Though automobile, electrical and electronics sectors typically dominate GVC participation in the world, the Kazakh automobile joint venture established in 2016 does not. Nor does its production of electrical machinery that is exported. Tariff and non-tariff restrictions discourage such participation. The home market for

\footnotetext{
17 The dollar value of exports since 2015 is yet to reach levels registered between 2011 and 2014 because world oil prices fell precipitously after 2014.

${ }^{18} \mathrm{High}$ value and more-differentiated 'worked' ferrous and non-ferrous metal products, the latter consisting of the following 4digit items: aluminum (6842), copper (6822), lead (6852), nickel (6832), zinc (6863).
} 
automobile is protected by import tariffs on new cars and import restrictions on used ones, while vehicle exports go mainly to countries of the Eurasian Union, including Russia, where they have favorable entry. ${ }^{19}$

Impact on Exports

30. The BRI impact on Kazakhstan's exports can be substantial. The completion of BRI transport projects in the CAC region and around the world is estimated to increase its exports by 3.7 percent ${ }^{20}$, which is higher than the average of 70 countries for which there are similar estimates (Baniya et al 2019). However, if BRI transport projects are accompanied by reforms in trade facilitation and logistics that halve the border-crossing delays, this export-impact could be magnified four-fold (i.e. exports could rise by 16 percent). Other scenarios also offer opportunities to increase exports. ${ }^{21}$

Figure 3: Trade is expected to increase, but much more if complemented by trade facilitation reforms (in \%)

(in \%, assuming 50 percent reduction in border delays and no maritime preference)
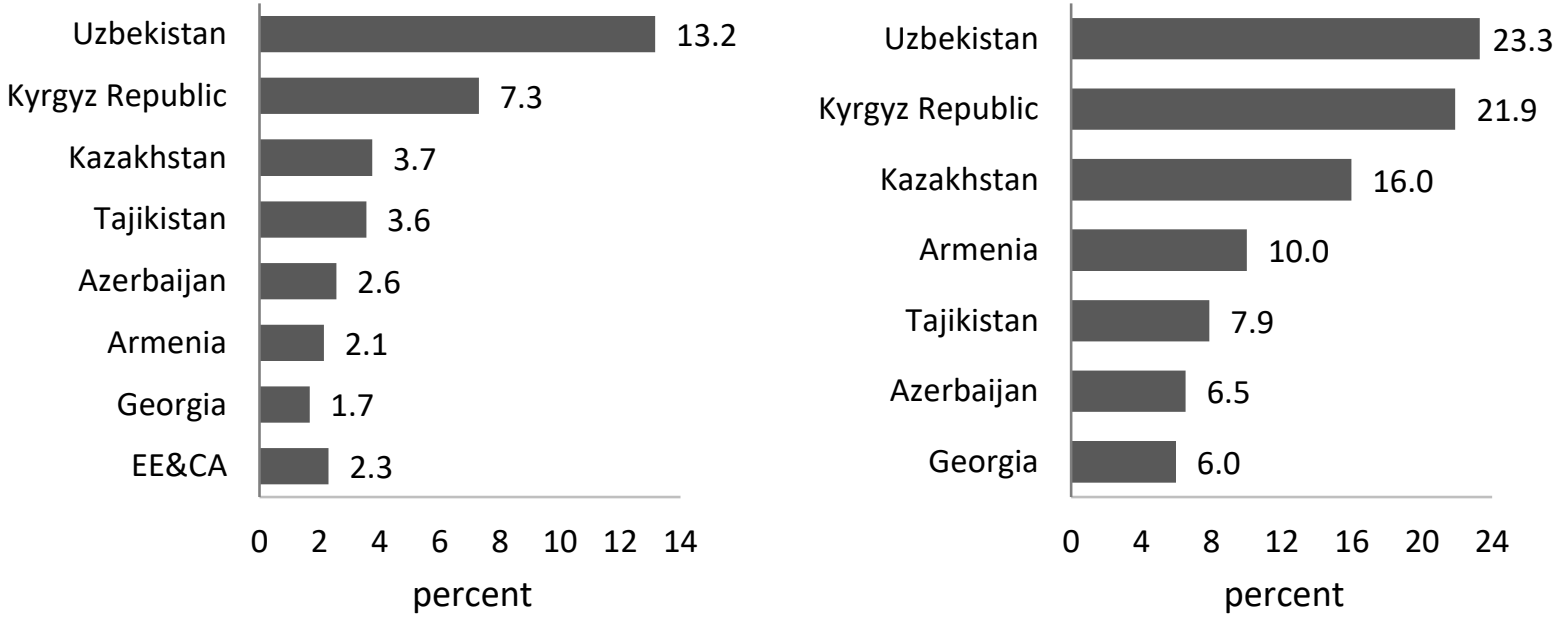

Source: Baniya et al. 2019

31. The impact that maybe of greater significance is the one on Kazakhstan's export composition. The favorable impact of lower shipment time on exports is greater for consumer items that depend more on time-sensitive external demand and for manufactured items that depend on time-sensitive imported inputs for their production. Baniya and other (2018) finds considerable variation in the responsiveness of exports to shipment time reduction across 15 groups of BRI countries' exports with some exports many times more responsive than others. The list of 15 includes the following product groups in descending order of export responsiveness to shipment time: wood products, glass products, vegetable products, mineral products, raw hides, skins and leather, animal products (e.g. meat), chemicals, metals, textiles, electrical machinery, transport equipment and footwear. Maliszewska and Van der Mensbrugge (2019) use a richer CGE model, where BRI-induced reductions in cost of imported inputs generate a reallocation of specializations across countries, to estimate the impact and find that the largest percentage increases in export volume are in respect of time-sensitive items in Central Asia's exports. Country specific estimates for Kazakhstan show that its agricultural exports could increase by more than 22 percent, processed foods

\footnotetext{
19 It is difficult to be a competitive producer of cars today without being part of a GVC.

20 This is an upper-bound estimate based on the assumption that shippers can switch transport modes from sea to rail when BRI improvements in transport make that switch optimal; lower-bound estimate is only 2.5 percent based on no switching.

${ }^{21}$ Scenarios analyzed include more efficiency corridor management, deepening trade agreements and improving market access.
} 
by nearly 17 percent, metal products by 11 percent and wood products by 8 percent; even exports of transport machinery could be 50 percent higher. Coal, oil and gas have the lowest responsiveness to BRI, with others arrayed in between the two groups.

32. Whether this boost to non-oil export items translates into sustained export growth will depend on whether conditions of domestic supply and external demand are favorable for these items. Over the last five years Kazakhstan has increased the number of goods in which it has revealed comparative advantage, including in metals and agriculture. ${ }^{22}$ Also, agricultural machinery and transport items like railway cars and motor vehicles are found to have potential as exports (IMF 2018). ${ }^{23}$ There is growing demand for wheat and meat from China, Iran and India. China is also interested in relocating many of its less hi-tech industries to neighboring countries, including metal products ${ }^{24}$ and machinery. Complementary policies to reduce tariff and non-tariff restrictions as well as improve domestic supply conditions in agriculture, metals and manufacturing can generate sustained growth in wheat, meat and metals (IFC 2017) and machinery.

$\begin{aligned} & \text { Table 5: Estimates of BRI Impact on Kazakhstan's Non-Oil Export Groups } \\
& \text { (\% increase from baseline) }\end{aligned}$
\begin{tabular}{|l|l|l|c|}
\hline \multicolumn{1}{|c|}{ Export Groups } & $\begin{array}{c}\text { Percent change } \\
\text { from baseline }\end{array}$ & Export Groups & $\begin{array}{c}\text { Percent change } \\
\text { From baseline }\end{array}$ \\
\hline Transport Equipment & 53.1 & Machinery & 2.5 \\
\hline Agriculture & 22.6 & Chemical, Rubber, Plastics & 2.3 \\
\hline Processed Foods & 16.9 & Wearing Apparel & 1.8 \\
\hline Metal Products & 11.0 & Leather goods & 1.7 \\
\hline Wood Products & 7.9 & Textiles & 1.5 \\
\hline Manufactures n.e.s & 6.6 & & \\
\hline
\end{tabular}

Source: Maliszewska and Van der Mensbrugge (2019)

\section{Impact on FDI}

33. The BRI is expected to increase overall FDI inflows to BRI countries. First, a reduction in shipment time raises competitiveness of exports, especially of those that are more time-sensitive, and thus encourages additional foreign investment in them. Second, under the BRI, outward FDI from Chinese private and SOEs to BRI countries is encouraged and is, in many cases, part and parcel of BRI efforts to catalyze trade and growth in these countries and promote deeper integration in general, and with China in particular. Recent estimates of the BRI impact on FDI (Chen and Lin 2018) confirm that reductions in shipment time would raise overall FDI as well as Chinese FDI. A 10 percent reduction in shipment time increases overall FDI flows into BRI countries by 12 percent on average, and Chinese FDI flows into them by 7 percent. The study estimates that the fall in shipment time will raise total FDI to Kazakhstan by 9 percent; there is no equivalent estimate on BRI impact on Chinese FDI.

34. Kazakhstan has generally been an attractive destination for foreign investors with most FDI inflows going into oil, gas and mineral sectors and little to agriculture and manufactures. Three quarter

\footnotetext{
22 The potential for growth in higher-value-added exports is considerable. Nearly 70 percent of metal exports consist of ores, concentrates and low-value upstream unwrought alloys Similarly, processed agriculture is a small share of current agricultural exports that consists mainly of wheat, vegetables, fruits, nuts while meat exports are negligible.

${ }^{23}$ Recent product-space analysis suggests that the complexity of these products relative to what are being exported make them potential exports for Kazakhstan (IMF 2018).

${ }^{24}$ China's rebalancing would like to move production towards the higher-tech ends of value-chains, for example in steel, focus on products like grain-oriented electrical steel, steel sheets for nuclear power stations and steel for high-speed rail bogie frames and train wheels while importing other types of less hi-tech steel that it still needs.
} 
of the Kazakh stock of FDI of more than US\$140 billion is from United States and countries of the European Union. ${ }^{25}$ China started investing in the early 2000s, mainly in hydrocarbons; its share in FDI stock has risen to 7 percent, compared to 4 and 3 percent respectively for Japan and Russia.

35. There have also been substantial inflows of Chinese outward FDI in recent years with more than 40 percent going to Kazakh sectors other than oil and gas. The Global Investment Tracker (GIT) shows that China has invested US\$14 billion between 2013 and 2018 of which 18 percent went into chemicals, 14 percent in metals and the rest in financial and other services. ${ }^{26}$ However, these numbers understate recent Chinese inflows into Kazakh agriculture and manufacturing because they do not cover transactions that are below US\$100 million while a substantial share of individual projects in agriculture and manufacturing are below that size.

36. Media reports confirm substantial Chinese investments in Kazakh agriculture, especially in agroprocessing, seed production and agricultural machinery. ${ }^{27}$ Chinese private firms initiated 19 agroindustrial investment projects amounting to US\$1.9 billion comprising of oil seed processing, beef, lamb, horsemeat and poultry production, vegetable-processing including products like tomato-paste as well as processing of grains. ${ }^{28} \mathrm{~A}$ joint venture between Zhannur-Astana and Tianyang Yinhai Seed Co. has established a seed cluster to transfer advanced practices in seed production and enhance availability of better-quality seeds.

\section{Impact on GDP}

37. The BRI can potentially have a large effect on GDP. Lower shipment time generates higher FDI and exports which in turn improves productivity and raises GDP. Lower shipment time can also lower prices of imported inputs and reduce production costs which once passed on to downstream industries results in reallocations of specialization within and across countries and raises productivity growth. (De Soyres 2019), using a structural general equilibrium model (SGE), estimate the impact of improved infrastructure alone on Kazakh GDP at 6.5 percent; while improving trade facilitation and reducing tariffs along the corridors will add around 15 percent bringing the total gains from improved infrastructure and trade policy and facilitation to 21 percent. (Maliszewska and Van der Mensbrugge 2019), uses a computable general equilibrium model (CGE), and estimates the impact on GDP at 15.4 percent (most of it from reduced border delays). Both estimates show that reforms in trade facilitation and logistics to double border-crossing efficiency provide the lion's share of benefit from BRI.

38. Taking into account the cost of building the infrastructure lowers the gains, though Kazakhstan continues to benefit. The welfare impact ${ }^{29}$ is calculated by comparing the long-term real income gains noted above with an estimate of the infrastructure cost that the country is expected to pay. This adjustment lowers the welfare gain for Kazakhstan to around 9 percent in a scenario of improved infrastructure, combined with reduced border delays and lowering of tariffs. Given that large transport projects frequently cost more than expected, welfare gains could be put at risk. This highlights the

\footnotetext{
25 IMF's CDIS data.

26 The GIT data compiled by AEI and Heritage Foundation covers dollar value of a single FDI transaction in a country by an individual Chinese firm, only for each transaction above US\$100 million.

27 In 2015, China and Kazakhstan signed an agreement for 51 different projects in oil-products, in chemicals, in metallurgy, agricultural processing and in tourism and logistics amounting to US\$27 billion.

${ }^{28}$ Private Chinese firms like Zhongfu Investment group, Zhejiang Rifa Investment, AIJIU, Evraziya Agroholding and Tianyang Yinhai Seed Co are investors together with COFCO and CITIC. See J. Farchy (2016) and Grain (2019)

${ }^{29}$ In the SGE model, welfare is defined as total consumer revenues divided by the relevant consumption price index. Total revenue takes into account payments to factors of production, revenues derived from the portfolio share and from import tariffs, and the cost of the transport infrastructure.
} 
importance of the complementary reforms that improve the integration gains and that strengthen fiscal institutions and governance.

Figure 4: Increases in GDP

(in \% from baseline, SGE analysis)

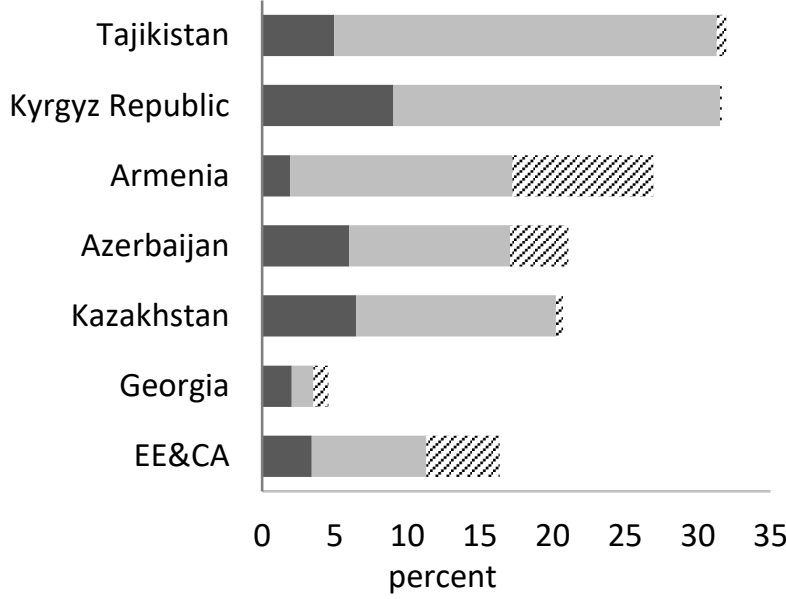

- Infrastructure improvement

Reduced border delays

$\geqslant$ Reduced tariffs

Source: de Soyres, Mulabdic and Ruta (2019)

\section{Spatial Impact}

39. Spatial analysis finds that the benefits of BRI-improvements in transport are likely to be associated with regional concentration of economic activity. Economic growth is unbalanced (World Bank, 2009); for example, urban hubs that are closer to border-crossings will gain disproportionately more while those farther away will be relative losers. The attractiveness of regional locations in terms of amenity and strength of comparative advantage count because transport improvements alone cannot offset disadvantages of unattractive locations. On the other hand, cities and regions with better amenities and a significant manufacturing sector can benefit substantially from its proximity to border areas and greater transport improvements because of the potential for increasing returns and agglomeration economies.

40. Improvements in BRI connectivity are likely to be associated with more spatial concentration, rather than dispersion of economic activity within countries; given Kazakhstan's economic structure this may mean bigger opportunities for some regions compared to others. Most of the gains expected from the improved connectivity do not accrue from the direct impact of the reduction in trade costs, rather, they accrue from income gains related to the response of economic agents which tend to increase scale and benefit from agglomeration by locating near other firms engaged in similar and related activities. Given the potential for agglomeration in Kazakhstan (sound manufacturing base, larger urban areas providing opportunities for specialization and clustering), the expected additional gains could be substantial. The results of a spatial general equilibrium model ${ }^{30}$ for Central Asia suggest that without economic adjustment, the gains from the decline in transport costs are around 1.9 percent for Kazakhstan, above the aggregate gains of 1.4 percent for the sub-region. However, the real income growth for Kazakhstan is lower in a scenario with very limited economic adjustment, or under the assumption that products traded internationally are differentiated by countries (i.e. consumers can change behavior, but firms remain in their location). Allowing for business to change location or assuming labor mobility and

\footnotetext{
30 The model analysis few scenarios of economic adjustment: a) Armington, where it is assumed that producers and consumers change behavior while number of firms remains unchanged; b) monopolistic competition where firms' entry and exit is allowed and c) increasing returns and labor mobility.
} 
increasing return to scale in manufacturing increases significantly the real income gains for Kazakhstan as economic activity concentrates in centers with bigger potential for agglomeration of economic activity.

Table 6: Real income gains, by country

\begin{tabular}{|l|r|r|r|r|}
\hline & $\begin{array}{c}\text { Direct effect } \\
\text { of transport } \\
\text { cost decline }\end{array}$ & Armington & $\begin{array}{l}\text { Average real income growth } \\
\text { Monopolistic } \\
\text { competition }\end{array}$ & $\begin{array}{l}\text { Increasing returns } \\
\text { and labor mobility }\end{array}$ \\
\hline China (3 provinces) & 1.2 & 1.2 & 2.0 & 2.5 \\
\hline Kazakhstan & 1.9 & 1.6 & 2.1 & 5.2 \\
\hline Kyrgyz Republic & 1.6 & 4.9 & 4.4 & 4.6 \\
\hline Pakistan & 1.5 & 1.8 & 2.3 & 6.3 \\
\hline Tajikistan & 1.6 & 1.7 & 1.5 & 1.0 \\
\hline Turkmenistan & 0.4 & 0.3 & 0.0 & -0.3 \\
\hline Uzbekistan & 0.7 & 0.8 & 1.0 & 1.6 \\
\hline Aggregate & 1.4 & 1.4 & 1.0 & 1.6 \\
\hline
\end{tabular}

Source: Belt and Road Economics

41. However, such a differentiated spatial impact also increases risks for part of the population. Specifically, several urban centers in Kazakhstan like Almaty, Nur Sultan, Dzhambul, Karaganda and Shymkent will thus benefit more than others (Lall and Lebrand 2019), and some districts could easily see a fall in income. In addition, even in these urban areas, note everyone will gain. In fact, industries that will face greater competition (for example, manufacturing) could lose jobs.

\section{Complementary Policies to Accompany BRI Investment}

42. The estimates of the BRI impact make clear that notwithstanding the importance of better transport infrastructure for trade and development only with complementary policies can countries maximize the benefits of their BRI investments in transport. This is particularly true in Kazakhstan where border crossing is still slow or where FDI inflow in business services is more restrictive or labor mobility is limited and so on. This section identifies some of the measures that may be needed in respect of trade facilitation and logistics, as well as in the areas of FDI in services.

a) Reform trade facilitation and logistics to reduce border delays: All estimates of BRI impact on exports and GDP highlight the importance of reducing border-crossing delays in parallel with BRI improvements in transport infrastructure. All indicators of the efficiency of crossing Kazakhstan's border highlight existing deficiencies in trade facilitation and logistics. While membership in the Eurasian Economic Union prevents Kazakhstan from unilaterally lowering tariffs, it could unilaterally streamline trade facilitation procedures, improve logistics and open up to services. Kazakhstan can also consider leveraging the electronic customs declaration system by setting an electronic platform for single-submission and synchronous processing of trade and logistics related documents (single-window).

b) Liberalize FDI in agriculture and business services: Complementing transport investments with the liberalization of FDI in finance and business services, can enhance the responsiveness of FDI and exports to a reduction in shipment time. Business services are crucial inputs into efficient production and export of processing agriculture and manufactures and Kazakhstan's restrictive FDI regime for services can raise the price and reduce the quality of such services. In telecommunications, FDI is deterred by restrictions on ownership of foreign investors to 49 percent or less of a firm or by awarding long exclusivity rights to incumbent operators for long distance and international services. Foreign banks operations in the country are restricted in various ways also, while in transportation services, railroad tariffs differentiate between imports, 
exports and domestic freight destinations with limited competition in freight services. In air transportation, domestic route licensing is restricted for foreign airlines. Making the regulatory regime in agriculture more attractive to FDI can help increase the sector's export potential.

c) Further improve the business environment. Kazakhstan ranks a respectable 25 position at the 2020 Doing Business report. However, limited improvement in areas not captured by the Doing Business report (state capture, vested interests, rule of law) has limited the emergence of a vibrant private sector. As a result, firm entry is low and Kazakhstan has one of the highest number of arbitrage cases per billion of FDI stock (second only to the Russian Federation). The limited vibrancy in the private sector is also reflected in the stagnant growth of corporate loans given by the banking sector.

Figure 5: Firm entry is low

(firm entry per 1,000 working age population)

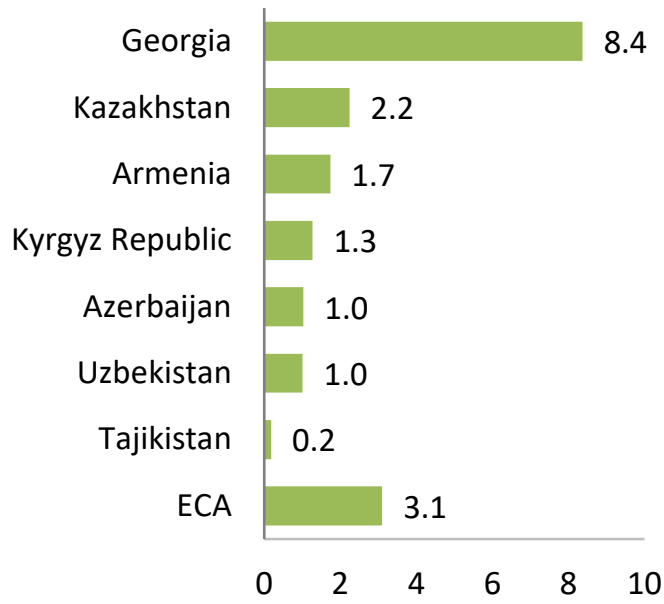

Source: World Bank

Note: Data is for 2016.
Figure 6: Investor-state dispute are frequent (arbitrage cases per US\$ billion in FDI)

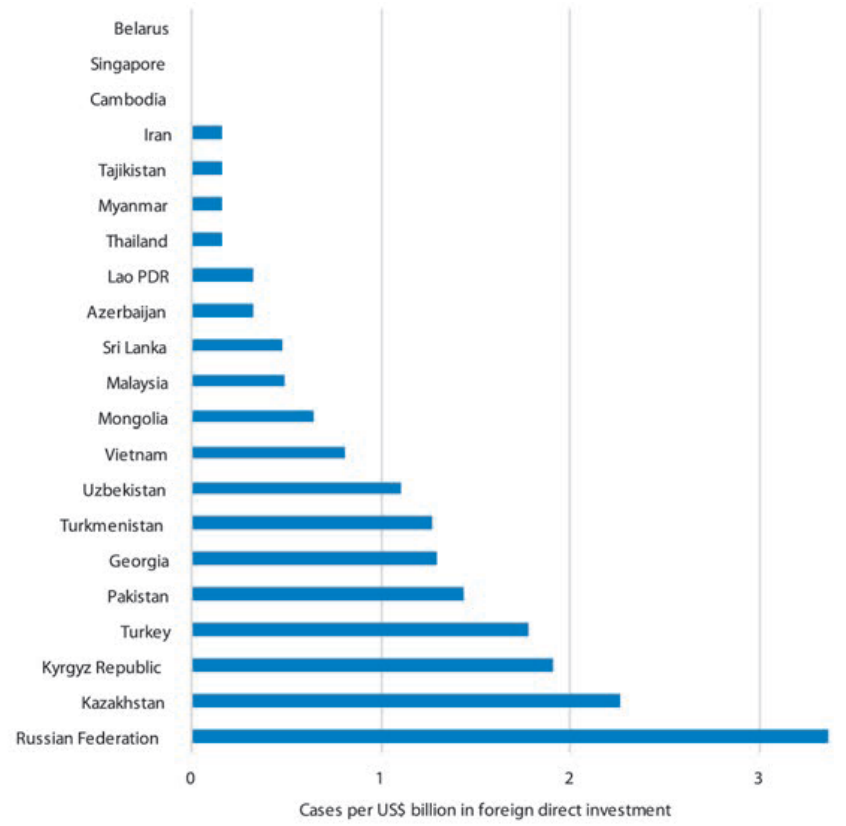

Source: Kher and Tran (2018), based on UNCTAD Investment Dispute Settlement Navigator.

d) Stronger regional cooperation: The estimated gains from improved infrastructure are conditional on the improvements being undertaken on the entire transport network. This calls for steppedup cooperation between countries. While there has been no lack of cooperation initiatives in South Caucasus and Central Asia, these appear to have had only limited usefulness. The CAC economies are parties to numerous trade and transport facilitation frameworks which aspire to create frameworks for more efficient trade and economic integration. ${ }^{31}$ However, selective coverage of trade and transport issues, complex rules, as well as lack of functioning dispute resolution mechanisms have limited their effectiveness. To strengthen regional cooperation, countries will need to build on the existing arrangements, but also establishing new ones. In addition, in the case of Kazakhstan, harmonization and standardization of procedures with

\footnotetext{
31 These include: the Eurasian Economic Community; the Shanghai Cooperation Organization; the Economic Cooperation Organization; the Transport Corridor Europe-Caucasus-Asia (TRACECA), the Central Asia Regional Economic Cooperation (CAREC) and so on.
} 
corridor countries will result in interoperability which is imperative for efficient and effective trade and transport flows along a corridor.

e) Facilitate labor mobility: The BRI-impact on exports and GDP is likely to be unequally distributed across Kazakh regions, especially because of low geographic mobility of labor. The country could continue to relax requirements for workers to register with local authorities, as these could be encouraging informality and reducing access to public services such as education. Importantly, urban hubs may not be well prepared to absorb the influx of workers; availability of affordable urban housing in the country's most prosperous cities as Almaty and Astana are key factors impeding the mobility of people from lower-income areas. Finally, cultural and social norms may be limiting mobility.

\section{Fiscal Risk of Scaling-Up Public Investment for BRI Infrastructure}

43. The scale and bunching of BRI transport investments and the size of borrowing to finance such investment and their terms have raised questions about medium-term debt sustainability of BRI countries. Kazakhstan has been a significant investor in BRI corridors over the last decade and it plans to invest more in future. It has used its own surplus resources and borrowing from multilateral sources for such investment. So far, the government has not borrowed from China for infrastructure.

44. Nevertheless, Kazakhstan's fiscal risk from BRI could stem from the size of scale-up of its public investment in BRI infrastructure and its financing. Assessing BRI specific fiscal risk is however difficult. Though a host of Kazakh rail and road projects ${ }^{32}$ have either been recently completed or are ongoing, there is no available data on the size of Kazakh public investment spending specifically on BRI corridor infrastructure.

45. Kazakhstan's fiscal situation weakened considerably after 2013 but quite independently of its investments in BRI corridor infrastructure. ${ }^{33}$ This was due mainly to the precipitous collapse in oil prices, the slowdown in partner-country growth and the large depreciation of the tenge (the local currency). The consequent adoption of countercyclical stimulus measures raised the non-oil fiscal deficit and off-budget spending further with both being financed by a drawdown of the Oil Fund's assets by US\$15 billion ${ }^{34}$ (i.e. assets fell from US\$73.2 billion in 2014 to US\$57.7 billion in 2018). Overall, the fiscal balance worsened sharply, moving from an average surplus of 4.0 percent in 2010-13 to a deficit of 3.4 percent of GDP in 2014-18. Fiscal deficits were moderate in the last few years and while public debt increased (from 12.6 percent in 2013), at around 20 percent of GDP in 2019 it was still low.

46. The country scaled up its public investment in BRI infrastructure, including as part of the countercyclical response to the oil price shock. As a result, a number of transport projects were completed or are under construction. This was done relatively judiciously by reducing total capital spending. In the face of falling revenues and rising current expenditures, the latter driven by higher social transfers, subsidies, transfers and interest, capital spending was compressed from nearly 6.5 percent of GDP to around 3 percent of GDP between 2010-13 and 2014-17. While this kept total expenditure in check, it may have crowded-out non-BRI investment projects.

\footnotetext{
32 Using a list of Kazakh transport projects along BRI corridor routes, De Soyres et al (2019) uses a bottom-up method to estimate that Kazakhstan will have spent a total of around US\$21 billion on BRI transport projects when they are completed.

${ }^{33} \mathrm{BRI}$ infrastructure and BRI corridor infrastructure refers to investments in Kazakh segments of the three BRI corridor routes in Box 1 passing through Kazakhstan.

${ }^{34}$ This raised borrowing and fiscal adjustment risks as they are based in part on the Oil Fund asset buffer.
} 
47. As a result, medium term debt sustainability was not endangered. The 2017 DSA (IMF 2018) classified it as a 'lower scrutiny' country as current and projected levels of debt-related indicators remained below their relevant thresholds. ${ }^{35}$ The worsening of fiscal outcomes due to the COVID-19 pandemic and the collapse in commodity prices are not expected to test sustainability. The government budget deficit is expected to increase to around 5 percent of GDP in 2020 (around 10 percent of GDP if the oil fund is included) but retreat over the medium-term as the economy recovers. Debt is expected to peak at close to 30 percent of GDP in 2021 and decline afterwards. However, successful consolidation of the fiscal deficit would require restraining total spending and prioritizing it to increase productivity and faster growth in the non-oil tradable sector. In addition, it will require increasing non-oil revenues, which has proven difficult to achieve so far.

48. The country has fiscal space to sustain public investment, including in BRI investments, without undermining debt sustainability. However, increasing investment further is unlikely to generate sufficient growth to prevent a weakening in the debt indicators (Bandiera and Tsiropoulos, 2019). The implementation of all BRI related projects in Kazakhstan over the next five-year period will add between 0.4-0.5 percent of GDP to investment per year but generate additional GDP growth of up between 0.1 percent in a given year. They conclude that the debt-to-GDP ratio resulting from such investment will be higher compared to a scenario without it. There could also be fiscal risks associated with investment projects (cost overruns, delays, overestimated benefits and so on) that could also affect the debt-situation adversely. In any case, Kazakhstan is a low scrutiny' country that could afford the above-mentioned BRI projects without undermining medium term debt sustainability.

49. To improve the prospects for fiscal solvency, Kazakhstan can strengthen its fiscal institutions further along several dimensions. First, given the multi-year implications of scaled up infrastructure investments and their recurrent spending requirements, establishing and implementing medium-term budget frameworks systematically can avoid frequent reallocations and/or delays in project-execution because of the need to re-prioritize investment annually to avoid unanticipated breach of deficit targets. Second, the public investment management (PIM) system needs to be strengthened. While projects are appraised and prioritized, the 2018 Public Expenditure and Financial Accountability (PEFA) assessment noted relatively limited transparency, including on total capital and lifetime costs and a somewhat weak system to monitor non-financial assets. In addition, there should be an institutionalized ex-post assessment of the adequacy of operations and maintenance (O\&M) budget for transport-projects, because there is a systematic bias in under-estimating O\&M at the stage of investment proposals ${ }^{36}$. Third, strengthening of the overall PFM framework, especially on public procurement and increasing accountability, can help in mitigating governance risks from scaled up public investment. According to the Worldwide Governance Indicators, Kazakhstan's ability to control corruption is limited, it performs better compared to other Central Asia countries, but trails significantly the ECA average. Finally, reforming the quasi-fiscal sector would be critical to limiting fiscal risks and improving service delivery, but also opening new opportunities for private sector growth.

50. The role of the private sector in infrastructure provision could also be strengthened, but this would require a strong capacity to monitor and mitigate fiscal risks. Kazakhstan has been accumulating experience with the engagement of the private sector in infrastructure over the last few decades; the World Bank's database on Private Participation in Infrastructure lists a number of projects, mostly in the

\footnotetext{
${ }^{35}$ A country is classified as 'lower scrutiny' if it is below all of the following DSA thresholds: current or projected public debt is below $50 \%$ of GDP; current or projected gross financing need is lower than $10 \%$ of GDP; the country is not seeking nor has it availed exceptional access to IMF resources.

${ }^{36} \mathrm{O} \& \mathrm{M}$ in local budgets, which account for more than three-quarters of public O\&M spending, has remained close to its nominal level in 2010, implying a systematic underestimation bias.
} 
power sector and prior to 2000. Since 2005, there have been only 11 projects, roughly equally split between transport (rail, airports, roads) and energy. Getting a more vibrant private sector engagement in infrastructure would require stronger government capacity to analyze projects, share risks as well as disclose and manage those risks. Sector policies would also need to be amended to ensure efficient pricing and regulation. According to the World Bank Procuring Infrastructure PPPs, the performance of Kazakhstan is above average for the sub-region but below those of more advanced peers, but there is considerable scope to improve.

Figure 7: Quality of PPP processes

(score, on a scale from 0 to 100 , higher values indicate better performance)

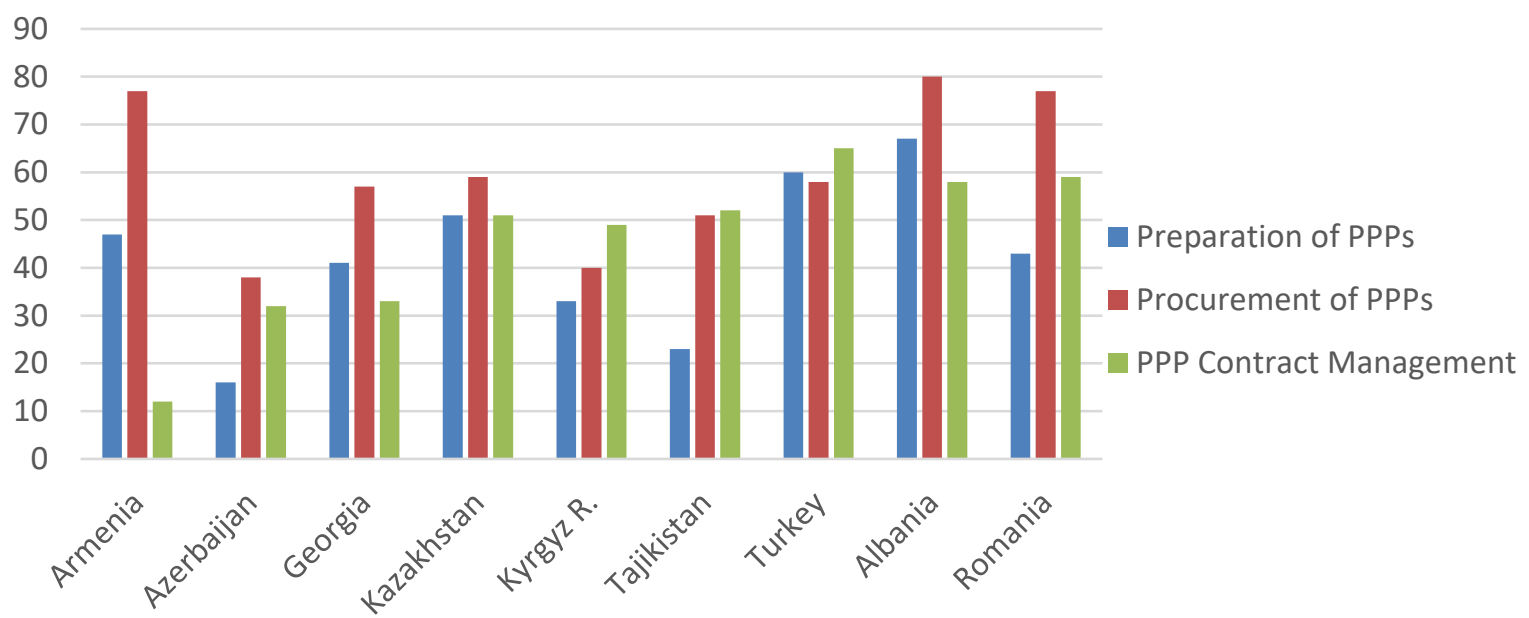

Source: World Bank Procuring Infrastructure Public-Private Partnership 


\section{References:}

Aldayarov, M., I. Dobozi, and T. Nikolakakis, 2017, "Stuck in Transition: Reform Experiences and Challenges Ahead in the Kazakhstan Power Sector", World Bank, Washington, DC.

Bandiera, L., and V. Tsiporoulos, 2019, "A Framework to Assess Debt Sustainability and Fiscal Risks Under the Belt and Road Initiative", Policy Research Working Paper 8891, World Bank, Washington, DC.

Baniya, S., N. Rocha, and M. Ruta, 2019, "Trade Effects of the New Silk Road: A Gravity Analysis", Policy Research Working Paper 8694, World Bank, Washington, DC.

Chen, M., and C. Lin, 2018, "Foreign Investment across the Belt and Road: Patterns, Determinants and Effects", Policy Research Working Paper 8607, World Bank, Washington, DC.

Constantinescu et al, 2019, "Central Asia and Caucuses Countries and the BRI: Key Facts and Figures", Unpublished Note, World Bank, Washington, DC.

De Soyres, F., A. Mulabdic, S. Murray, N. Rocha, and M. Ruta, 2018, "How Much Will the Belt and Road Initiative Reduce Trade Costs?”, Policy Research Working Paper 8614, World Bank, Washington, DC.

De Soyres, F., A. Mulabdic, and M. Ruta, 2019, “Common Transport Infrastructure: A Quantitative Model and Estimates from the Belt and Road Initiative", Policy Research Working Paper 8801, World Bank, Washington, DC.

Farchy, Jack, 2016, “China Plans to Invest $\$ 1.9$ billion in Kazakh Agriculture”, Financial Times.

GRAIN, 2019, "The BRI: Chinese Agribusiness Going Global".

IFC, 2017, "Creating Markets in Kazakhstan: Country Private Sector Diagnostic", Washington. DC.

IMF, 2018, "Kazakhstan-Selected Issues", IMF Country Report No 18/278, Washington, DC.

Maliszewska, M., and D. Van der Mensbrugghe, 2019, "The Belt and Road Initiative: Economic, Poverty and Environmental Impacts", Policy Research Working Paper 8814, World Bank, Washington, DC.

Mikou, M., J. Rozenberg, E. Koks, C. Fox, and T.P. Quiros, 2019, “Assessing Rural Accessibility and Rural Roads Investment Needs Using Open Source Data”, Policy Research Working Paper 8746, World Bank, Washington, DC.

NDRC, MOF and MOC, 2015, "Visions and Actions on Jointly Building Silk Road Economic Belt and 21stCentury Maritime Silk Road". Government of China, Beijing.

Reed, T., and A. Trubetskoy, 2019, "Assessing the Value of Market Access from Belt and Road Projects", Policy Research Working Paper 8815, World Bank, Washington, DC.

Starr, F., J. Engvall, and S. E. Cornell, 2016, "Kazakhstan in 2041: The Next 25 Years", Silk Road Paper, Central Asia and Caucuses Institute, John Hopkins University, Washington, DC.

Shepard, W., 2016, "How those China-Europe 'Silk Road' Trains first began", Forbes.

World Bank, 2009, "World Development Report 2009: Reshaping Economic Geography", Washington, DC. https://openknowledge.worldbank.org/handle/10986/5991

World Bank, 2016, "Turning the Tide in Turbulent Times: Leveraging Trade for Kazakhstan's Development', Washington, DC.

World Bank, 2017, "Kazakhstan Public Finance Review: Enhancing the Fiscal Framework to Support Economic Transformation”, Washington, DC. 
World Bank, 2018, "Kazakhstan: A New Growth Model for Building a Secure Middle Class, Systematic Country Diagnostic", Washington, DC.

World Bank, 2019, "Belt and Road Economics: Opportunities and Risks of Transport Corridors", Washington, DC.

World Bank, 2020, "Global Economic Prospects, June 2020", Washington, DC. https://openknowledge.worldbank.org/handle/10986/33748

Zeynalova, Leman, 2018, "China's HKC Corporation interested in plant construction in Kazakhstan." https://en.trend.az/business/economy/2937314.html. 
Annex: BRI Transport Projects in the Central Asia and Caucuses Region

\begin{tabular}{|c|c|c|c|}
\hline BRI Transport Projects & New, Upgrades and Expansion & Countries & $\begin{array}{l}\text { Status: Operational, } \\
\text { Ongoing, Planned }\end{array}$ \\
\hline Urumqi-Khorgas rail proj. & Urumqi-Khorgas new rail link & China & -2012 \\
\hline Khorgas New Dry Port & $\begin{array}{l}\text { New Rail Terminal, Truck } \\
\text { Terminal, Logistics Center \& Free } \\
\text { Trade Zone }\end{array}$ & China, Kazakhstan & $\begin{array}{l}-2012 \text { (partly) } \\
-2015 \text { (fully) }\end{array}$ \\
\hline Moscow-Kazan rail proj. & $\begin{array}{l}\text { Moscow-Kazan High Speed Rail } \\
\text { upgrade }\end{array}$ & Russia & -Under construction \\
\hline Khorgas-Aktau Rail Project & $\begin{array}{l}\text {-Khorgas-Zhetigan (293 km) } \\
\text {-Jezkazgan-Saksaulsky (546 km) } \\
\text {-Beyneu-Salkar }\end{array}$ & Kazakhstan & $\begin{array}{l}-2014 \\
-2014 \\
-2016\end{array}$ \\
\hline Aktau Seaport Expansion & $\begin{array}{l}\text {-Sealink } \\
\text {-Container port } \\
\text {-Expansion of Port Facilities }\end{array}$ & Kazakhstan & $\begin{array}{l}-2000 \\
-2014 \\
- \text { Under construction }\end{array}$ \\
\hline $\begin{array}{l}\text { North South Uzen-Gorgan } \\
\text { rail proj. }\end{array}$ & $\begin{array}{l}\text {-Uzen-Bolashak } \\
\text {-Serkhetyaka-Bereket- Iran } \\
\text { border } \\
\text {-TKM border-Gorgan }\end{array}$ & $\begin{array}{l}\text { Kazakhstan } \\
\text { Turkmenistan } \\
\text { Iran }\end{array}$ & $\begin{array}{l}-2013 \\
-2014\end{array}$ \\
\hline Baku-Alyat seaport & $\begin{array}{l}\text {-Sea-link to Aktau } \\
\text {-Sea link to Turkmenbashi }\end{array}$ & $\begin{array}{l}\text { Azerbaijan, Kazakhstan } \\
\text { Turkmenistan }\end{array}$ & $\begin{array}{l}-2014 \\
-2016\end{array}$ \\
\hline $\begin{array}{l}\text { Baku-Tiblisi-Kars-Istanbul } \\
\text { rail proj. }\end{array}$ & $\begin{array}{l}\text { Baku-Tbilisi upgrade } \\
\text { Tbilisi-Kars new rail segment }\end{array}$ & $\begin{array}{l}\text { Azerbaijan, Georgia } \\
\text { Georgia, Turkey }\end{array}$ & $\begin{array}{l}-2016 \\
-2017\end{array}$ \\
\hline Marmaray Tunnel & Marmaray rail project & Turkey & -Under construction \\
\hline $\begin{array}{l}\text { Kashgar-Pap Tashkent rail } \\
\text { project }\end{array}$ & $\begin{array}{l}\text { Kashgar-Irkeshtam-Osh rail proj } \\
\text { Angren-Pap rail link to Tashkent }\end{array}$ & $\begin{array}{l}\text { China, Kyrgyz Republic } \\
\text { Uzbekistan }\end{array}$ & $\begin{array}{l}\text {-Proposed } \\
-2015\end{array}$ \\
\hline Samarkand-Mashad rail & $\begin{array}{l}\text { Samarkand-Mary-Sarahs-Serakhs- } \\
\text { Mashad upgrade }\end{array}$ & $\begin{array}{l}\text { Uzbekistan, Iran, } \\
\text { Turkmenistan }\end{array}$ & -2016 \\
\hline Mashad-Tehran rail Upgrade & Mashad- & Iran & -Ongoing \\
\hline Kashgar-Dushanbe rail proj. & $\begin{array}{l}\text { Kashgar-Irkehstam-Karamyk- } \\
\text { Dushanbe new rail link }\end{array}$ & $\begin{array}{l}\text { China, Kyrgyz Republic, } \\
\text { Tajikistan }\end{array}$ & -Proposed \\
\hline SherKhan_Herat rail & $\begin{array}{l}\text { SherkhanBandar-Kunduz- } \\
\text { MazareSharif-Herat new rail \& } \\
\text { upgrade }\end{array}$ & Afghanistan & -Under construction \\
\hline \multicolumn{4}{|l|}{ Dry ports and hubs } \\
\hline $\begin{array}{l}\text { Atyrau, Shymkent, Astana, } \\
\text { Almaty }\end{array}$ & & Kazakhstan & $\begin{array}{l}\text { Except for Astana, } \\
\text { proposed for } \\
\text { modernization \& } \\
\text { expansion }\end{array}$ \\
\hline $\begin{array}{l}\text { Andijan, Samarkand, } \\
\text { Bukhara }\end{array}$ & & Uzbekistan & \\
\hline Bishkek, Osh & & Kyrgyz Republic & \\
\hline $\begin{array}{l}\text { Tursunzade, NiznyPanj, } \\
\text { Jirgital }\end{array}$ & & Tajikistan & \\
\hline
\end{tabular}

Source: Reed \& Trubetskoy (2018) compiled a list of BRI projects from which projects in the CAC region are cited. 